FINANCIAL: Jurnal Akuntansi

Published by Program Studi Akuntansi STIE Sultan Agung Volume 7-Nomor 2, Desember 2021, (HIm 133-142)

ISSN-P: 2502-4574, ISSN-E: 2686-2581

Available online at: https://financial.ac.id/index.php/financiaI

\title{
ANALISIS PAJAK HOTEL DAN PAJAK PARKIR PADA PAJAK DAERAH KABUPATEN PANDEGLANG SEBELUM DAN SESUDAH TSUNAMI SELAT SUNDA
}

\author{
Tri Wahyudi \\ Program Studi Akuntansi, Universitas Sultan Ageng Tirtayasa, Jl. Raya Palka No.Km 3, Panancangan, \\ Kec. Cipocok Jaya, Serang, Banten 42124, Indonesia. \\ E-mail: tri.wahyudi@untirta.ac.id
}

\begin{abstract}
Abstrak
Pajak Daerah adalah bagian dari sumber Pendapatan Asli Daerah (PAD) dan merupakan tolok ukur bagi penilaian kemandirian di suatu pemerintah daerah. Dalam rangka meningkatkan Pajak Daerah Kabupaten Pandeglang, sumber-sumber penerimaan daerah harus bisa dioptimalkan. Pajak Hotel dan Pajak Parkir termasuk kedalam Pajak Daerah. Kabupaten Pandeglang memiliki keunikan potensi daerah terutama terhadap 2 (dua) kondisi/ keadaan yang pernah terjadi di daerah Kabupaten Pandeglang yaitu sebelum dan sesudah tsunami selat sunda (22 Desember 2018). Tujuan dari penelitian ini adalah untuk mengetahui kontribusi Pajak Hotel dan Pajak Parkir terhadap Pajak Daerah serta untuk mengetahui pergerakan naik atau turunnya pajak-pajak tersebut dengan cara membandingkan antara target/perencanaan dan realisasi penerimaan pajak di tahun 2015 s.d. 2019. Penelitian ini merupakan penelitian deskriptif kuantitatif dengan metode pengumpulan, pengolahan, dan penganalisisan data. Hasil penelitian yang diperoleh diantaranya 1) Terdapat penurunan kontribusi Pajak Hotel terhadap realisasi Pajak Daerah sebelum dan sesudah terjadi bencana tsunami selat sunda meskipun masih mencapai target atas Pajak Hotel disetiap tahunnya. 2) Kontribusi realisasi atas Pajak Parkir terhadap Pajak Daerah sebelum dan sesudah terjadi bencana tsunami selat sunda cenderung sama, meskipun mengalami peningkatan atas Pajak Parkir ditahun 2019 (setelah bencana tsunami) berbanding lurus dengan target penerimaan atas Pajak Parkir di setiap tahunnya.
\end{abstract}

Kata Kunci: Pajak Daerah, Pajak Hotel, Pajak Parkir

\section{ANALYSIS OF HOTEL TAX AND PARKING TAX ON REGIONAL TAXES OF PANDEGLANG REGENCY BEFORE AND AFTER THE SELAT SUNDA TSUNAMI}

\begin{abstract}
Regional Tax is part of the source of Regional Original Income and is a benchmark for the assessment of independence in a regional government. In order to increase the Regional Tax of Kabupaten Pandeglang, the sources of regional revenue must be optimized. Hotel Tax and Parking Tax are included in the Regional Tax. Kabupaten Pandeglang has a unique regional potential, especially regarding 2 (two) conditions that have occurred in Kabupaten Pandeglang, namely before and after the Selat Sunda Tsunami (December 22 ${ }^{\text {nd }}, 2018$ ). The purpose of this study is to determine the contribution of Hotel Tax and Parking Tax to Regional Taxes and to determine the movement of these taxes up or down by comparing the target/planning and the realization of tax revenues in 2015 until 2019. This research is a quantitative descriptive study with data collection, processing, and analysis methods. The research results obtained include 1) There is a decrease in the contribution of Hotel Tax to the realization of Regional Original Taxes before and after the Selat Sunda tsunami disaster, although it still reaches the target of Hotel Tax every year. 2) The contribution of the realization of the Parking Tax to the realization of the Regional Original Tax before and after the selat sunda tsunami disaster tends to be the same, although the increase in the Parking Tax in 2019 (after the tsunami disaster) is directly proportional to the revenue target of the Parking Tax every year.
\end{abstract}

Keywords: Regional Tax, Hotel Tax, Parking Tax

Article History: Received: 28 Jul 2021 Revised: 07 Okt 2021 Accepted: 27 Okt 2021 


\section{PENDAHULUAN}

Tsunami pernah terjadi di Kabupaten Pandeglang tepatnya pada tanggal 22 Desember 2018. Bencana tsunami menurunkan minat para wisatawan baik dari dalam maupun dari luar daerah. Menurut data Kementerian Pariwisata yang bersumber dari Tourism Crisis Center (TCC) diperoleh data bahwa sebanyak 69 (enam puluh sembilan) hotel dalam kondisi rusak ringan sampai dengan berat. Menurunnya jumlah wisatawan membuat turunnya tingkat pendapatan dari masyarakat setempat termasuk pendapatan daerah (Aji, 2021). Penurunan wisatawan tidak hanya wisatawan yang menginap dilokasi hotel - hotel disekitar pantai tetapi dirasakan juga bagi wisatawan yang melakukan kunjungan tanpa menginap, hal tersebut bisa terlihat dari jumlah kendaraan yang masuk dan parkir di daerah - daerah wisata di Kabupaten Pandeglang.

Penghasilan pemerintah bersumber salah satunya dari pajak, menurunnya wisatawan akan berdampak pada berkurangnya salah satu pendapatan pemerintah daerah khususnya (Widodo \& Guritno, 2017). Pajak berperan untuk membantu pemerintah dalam menjalankan fungsi mengatur pemerintahan. Pembiayaan perlu dibuat secara baik mengikuti perencanaan anggaran yang telah dibuat oleh Pemerintah Daerah. Perencanaan yang dibuat oleh Pemerintah Daerah dirancang berdasarkan kinerja tahun - tahun sebelumnya, dengan tetap memperhatikan kondisi lingkungan saat ini dan yang akan datang. Bentuk perencanaan pembiayaan yang ada di dalam suatu Pemerintahan Daerah hubungannya dengan masyarakat khususnya terkait dengan bidang kesehatan dan pendidikan. Selain bidang kesehatan dan pendidikan terdapat pula pembiayaan operasional seperti biaya belanja pegawai serta adminisrasi pemerintahan. Besarnya biaya pemerintah daerah akan berbanding lurus terhadap rencana/ target penerimaan daerah. Perbaikan infrastruktur juga nantinya akan menjadi perhatian pemerintah daerah untuk bisa lebih meningkatkan potensi masyarakat serta mengembangkan perekonomian daerah (Aji, 2021). Selain itu, perbaikan tersebut dapat lebih memberikan kenyamanan tidak hanya bagi masyarakat lokal termasuk di dalam nya para wisawatan dalam dan luar daerah yang hendak berkunjung ke Kabupaten Pandeglang.

Upaya pemerintah daerah untuk meningkatkan pendapatan, bergantung pada usaha atau kreasi pemerintah itu sendiri dalam mengelola keuangan (Mufidah et al., 2017). Adanya otonomi daerah memberikan peluang untuk bisa meningkatkan pendapatan daerah (Yusmalina et al., 2020). Undang undang Nomor 28 Tahun 2009 mengatur tentang pajak daerah dan restribusi daerah sebagai bagian dari sumber Pendapatan Asli Daerah. Berhasilnya pembiayaan pemerintah daerah akan sangat bergantung pada Pendapatan Asli Daerah yang salah satu nya bersumber pada pajak daerah (Pratama et al., 2017). Pajak daerah meliputi semua pendapatan yang bersumber atau berada di daerah diantaranya pajak hotel, pajak restoran, pajak hiburan, pajak reklame, pajak penerangan jalan, pajak pengambilan bahan galian golongan $\mathrm{C}$, pajak parkir, pajak bumi dan bangunan, pajak, bea perolehan atas tanah dan bangunan, pajak sarang burung wallet, pajak pengambilan dan pemanfaatan air bawah tanah. Dengan adanya otonomi daerah dan jenis sumber pendapatan daerah menjadikan tantangan tersendiri bagi pemerintah daerah untuk bisa mengembangkan daerahnya.

Perencanaan Pendapatan Asli Daerah Kabupaten Pandeglang setiap tahunnya 
mengalami peningkatan, dan diikuti dengan peningkatan realisasi atas penerimaan pajak daerah, hanya saja terdapat perbedaan dengan kondisi setelah bencana tsunami. Berdasarkan data Efektivitas tetap akan dikaitkan dengan tujuan dan sasaran yang akan dicapai oleh setiap daerah (Yohanis, 2018).

Pajak Daerah Kabupaten Pandeglang periode tahun 2015 - 2019 dari sektor pajak hotel dan parkir belum mampu memberikan kontribusi yang optimal, dikarenakan hotel dan tempat wisata di beberapa wilayah Kabupaten Pandeglang terkena dampak tsunami sehingga pendapatan usaha hotel dan parkir secara tidak langsung berpotensi mengalami penurunan. Usaha mengoptimalkan penerimaan pajak hotel dan pajak parkir daerah memerlukan perhatian khusus dari Badan Pelayanan Pajak Daerah Kabupaten Pandeglang yang sesuai wewenangnya sebagai koordinator dalam pemungutan pajak hotel dan pajak parkir. Diantara indikator yang mencerminkan kemandirian dan keberhasilan suatu daerah adalah dari adanya penerimaan atas pajak daerah.

Penelitian ini penting untuk melihat dan mengukur trend pajak daerah sebelum dan sesudah bencana yang terjadi, terkait perlu tidak nya perbaikan atau perubahan regulasi dan atau kebijakan serta pembaharuan sistem dalam rangka meningkatkan kepercayaan masyarakat serta penerimaan daerah disetiap tahunnya baik itu sebelum maupun sesudah bencana tsunami di Kabupaten Pandeglang.

\section{LANDASAN TEORI}

Undang - undang Republik Indonesia bersama dengan Peraturan Daerah mengatur tentang Pendapatan Asli Daerah. Pendapatan Asli Daerah bersumber dari masing - masing Copyright (C) 2021, FINANCIAL: Jurnal Akuntansi wilayah dan merupakan potret kemandirian serta keberhasilan dari suatu daerah. Pendapatan Asli Daerah sangat penting dalam membiayai kebutuhan administrasi, serta pembangunan didaerahnya (Siregar, 2017). Pendapatan Asli Daerah merupakan keseluruhan atau sebagian pendapatan atau penerimaan yang berasal dari daerah meliputi pajak daerah, dan retribusi daerah serta sumber pendapatan lainnya yang sah. Perimbangan keuangan dibagi menjadi 2 (dua) yaitu Pemerintah Pusat dan Pemerintah Daerah sebagaimana peraturan UndangUndang nomor 33 tahun 2004 tentang Perimbangan Keuangan antara Pemerintah Pusat dan Pemerintah Daerah.

Pajak Daerah ialah bagian dari pendapatan daerah yang memberi kontribusi secara luas terhadap Pendapatan Asli Daerah (Aznedra, 2017). Pajak bersifat wajib untuk dibayar berdasarkan peraturan undangundang tanpa balas jasa secara langsung. Pajak daerah ialah iuran dari personal atau lembaga/ badan kepada pemerintah daerah tanpa diikuti dengan balas jasa secara langsung berdasarkan peraturan daerah (Mardiasmo, 2018). Pajak daerah ialah pajak ditangan pemerintah daerah, dalam hal pengelolaannya dibawah pimpinan daerah diantaranya gubernur dan walikota/ bupati.

Pajak Hotel adalah kewajiban membayar atas layanan/ kemudahan yang diberikan oleh hotel termasuk fasilitas hotel seperti olahraga dan hiburan yang.disediakan oleh hotel (Fitriyani et al., 2021). Pengertian lain dari hotel adalah tempat menginap yang meminta adanya bayaran dengan beberapa macam pelayanan sarana dan prasarana penginapan atau berupa pelayanan sarana dan prasarana tinggal untuk waktu tertentu seperti wisma, kamar kos, gedung pertemuan dan penginapan wisata (Yafitzam, 2021). 
Landasan hukum atas Pajak Hotel adalah sebagai berikut: 1) Undang-undang No. 28 Tahun 2009 yang mengatur tentang Pajak Daerah dan Retribusi Daerah, 2) Undang-undang No. 34 Tahun 2000 yang merupakan perubahan atas Undang-undang Nomor 18 Tahun 1997 yang mengatur tentang Pajak Daerah dan Retribusi Daerah., 3) Peraturan Pemerintah No. 65 Tahun 2001 yang mengatur tentang Pajak Daerah, 4) Peraturan daerah Kabupaten/Kota yang mengatur tentang Pajak Hotel (khusus Kabupaten Pandeglang yaitu Peraturan Daerah nomor 1 tahun 2011), 4) Objek dari Pajak Hotel ialah layanan yang ada di hotel melalui pembayaran, termasuk fasilitas untuk menunjang kelengkapan hotel yang bertujuan memberikan kebermanfaatan dan keleluasaan, seperti fasilitas kebugaran dan entertainment.

Sarana dan prasarana lainnya sebagai bagian dari penunjang hotel yaitu alat komunikasi serta alat pengirim pesan atau surat lainnya. Pengenaan atas Pajak Hotel menjadi objek pajak diantaranya pelayanan dalam bentuk: 1) Sarana dan Prasarana inap untuk waktu tertentu. Dalam definisi rumah diantaranya kos-kosan sebanyak sepuluh atau lebih dari dari sepuluh kamar, 2) Pelayanan lainnya bagian dari kelengkapan sarana dan Prasarana inap untuk waktu tertentu yang bersifat memiliki nilai kebermanfaatan dan keluasaan, 3) Fasilitas kebugaran dan entertainment yang ada khusus untuk para tamu, 4) Sewa tempat berikut jasa kegiatan yang ada di hotel.

Dasar pengenaan pajak ialah sejumlah bayaran/ nilai bayar ke pihak hotel, dantidak terbatas pada kos - kosan, penginanpan dengan konsep wisma, pengianapan wisata serta aula pertemuan. Besaran Pajak Hotel ditetapkan maksimal sebesar $10 \%$ (sepuluh persen) dengan berdasarkan pada Peraturan Copyright (C) 2021, FINANCIAL: Jurnal Akuntansi
Daerah Kabupaten Pandeglang Nomor 1 Tahun 2011 tentang Pajak Daerah.

Pajak parkir diatur dalam beberapa peraturan diantaranya (1) Undang-undang No.28 Tahun 2009 tentang Pajak Daerah dan Retribusi Daerah, (2) Peraturan Pemerintah No.55 Tahun 2016 tentang Ketentuan Umum dan Tata Cara Pemungutan Pajak Daerah serta (3) Peraturan Daerah No.1 Tahun 2011 tentang Pajak Daerah, dari peraturan tersebut saling terkait sehingga didapatkan ketentuan terkait Pengenaan Pajak Parkir sebagai Pajak Daerah.

Parkir berdasarkan ketentuan peraturan merupakan bagian dari suatu kondisi sebagai suatu keadaan atau kondisi diam dari suatu kendaraan yang bersifat tidak tetap atau sementara. Penyelenggaraan tempat untuk parkir bisa pada sisi luar badan jalan, baik itu yang disediakan berhubungan dengan inti usaha maupun yang disediakan sebagai penunjang suatu usaha, termasuk usaha penyediaan tempat bagi penitipan kendaraan bermotor. Penyelenggara tempat parkir apabila tidak memungut sewa parkir kepada penerima jasa parkir, tetap akan dikenakan pajak parkir dengan dasar pengenaan pajak parkir yaitu dihitung dari luas area parkir dibandingkan dengan jumlah rata-rata kendaraan yang diparkir setiap hari, serta jumlah hari operasional tempat penyelenggaraan parkir dalam 1 (satu) bulan. Pajak parkir ini berlaku atau dikenakan kepada personal atau orang pribadi dan juga dapat dikenakan ke badan usaha.

Pajak parkir menurut statusnya dibagi menjadi 5 (lima) golongan (Rabiyah, 2019) yaitu parkir umum, parkir khusus, parkir darurat, taman parkir, dan gedung parkir

Parkir umum ialah suatu tempat yang memiliki fungsi sebagai perparkiran suatu kendaraan yang dikelola oleh pemerintah daerah lokasinya dapat berupa jalan-jalan, 
tanah-tanah, atau lapangan milik atau yang dikuasai pemerintah daerah. Parkir khusus ialah suatu tempat parkir dengan menggunakan tanah-tanah yang dikuasai. yang disediakan dan dikelola oleh Pihak Ketiga. Parkir darurat adalah tempat umum yang digunakan dalam kegiatan insentil oleh pemerintah daerah atau swasta. Taman parkir adalah suatu tempat perparkiran dengan menggunakan berupa jalan-jalan, tanahtanah, atau lapangan milik yang dikuasai yang diselenggarakan atau dikelola oleh pemerintah daerah dengan dilengkapi fasilitas dan sarana taman di perparkiran. Gedung parkir adalah suatu tempat parkir didalam suatu ruangan serta mendapatkan izin khusus sebagai tempat perparkiran dan diselenggarakan oleh pemerintah daerah atau pihak ketiga.

Objek dari Pajak Parkir ialah kegiatan penyelenggaraan daerah parkir bisa di sisi luar dari badan jalan, yang merupakan inti dari usaha atau usaha penunjang dari perorangan atau badan usaha, termasuk usaha dalam penyediaan tempat penitipan bagi kendaraan bermotor. Menurut UndangUndang No 28 Tahun 2009 tentang Pajak Daerah dan Retribusi Daerah pasal 62 ayat (2) dijelaskan bahwa yang tidak termasuk dalam objek pajak parkir diantaranya: 1) Penyelenggaraan tempat parkir oleh Pemerintah Pusat dan Pemerintah Daerah; 2) Penyelenggaraan tempat parkir dari perkantoran yang digunakan hanya untuk karyawannya sendiri; 3) Penyelenggaraan tempat parkir oleh konsulat, kedutaan, dan perwakilan dari negara asing berdasarkan asas timbal balik; 4) Penyelenggaraan penitipan kendaraan bermotor dengan kapasitas maksimal 10 (sepuluh) kendaraan roda 4 (empat) atau lebih atau kendaraan dengan kapasitas maksimal 20 (dua puluh) untuk kendaraan roda 2 (dua); 5)
Penyelenggaraan tempat parkir yang sengaja dibuat sebagai media pemasaran penjualan kendaraan bermotor.

Parkir dikenakan kepada orang pribadi maupun badan/ lembaga yang memanfaatkan lahan untuk parkir kendaraan, yaitu subjek Pajak Parkir adalah orang pribadi atau badan yang melakukan parkir kendaraan bermotor. Tarif pajak parkir ditentukan besarannya paling tinggi sebesar 30\% (Undang - Undang Republik Indonesia Nomor 28 Tentang Pajak Daerah Dan Restribusi Daerah, 2009). Penentuan tarif maksimal bertujuan agar memberikan kesempatan seluas-luasnya kepada pemerintah daerah agar bisa lebih optimal dalam membangun daerahnya sesuai dengan potensi daerahnya masing - masing (Puspita et al., 2016).

\section{METODE}

Penelitian ini masuk dalam kategori penelitian deskriptif kuantitatif dimana penelitian ini mempunyai tujuan memberikan kondisi secara nyata tentang hubungan di antara variabel yang ada. Metode deskriptif ialah metode yang dipakai untuk menganalisis atau menggambarkan dari suatu hasil penelitian tetapi tidak untuk dipakai guna mengambil kesimpulan secara lebih luas (Sugiyono, 2019)

Penelitian ini berlangsung di Kantor Badan Pelayanan Pajak Daerah (BP2D) Pandeglang dengan alamat di Jalan Pandeglang, Kec. Pandeglang, Kabupaten Pandeglang, Banten 42211. Adapun waktu penelitian dimulai dari bulan April sampai Mei 2021.

Langkah pertama yang diambil adalah dengan mencari fenomena yang ada, terkait dengan informasi, ramai/ padatnya kembali kawasan wisata di wilayah Kabupaten Pandeglang setelah terjadinya bencana tsunami selat sunda untuk dijadikan sebagai 
bagian dari rumusan permasalahan yang ada, dilihat dari sisi pendapatan perpajakan.

Tahapan selanjutnya adalah mengumpulkan data dengan cara observasi secara langsung ke Badan Pelayanan Pajak Daerah (BP2D) Kabupaten Pandeglang dengan melalui metode wawancara dengan pengawai dan pimpinan guna mendapatkan data yang dibutuhkan dalam penelitian ini. Data yang digunakan yaitu berupa data target dan realisasi atas pajak daerah di tahun 20152019. Periode ini dipilih karena masuk dalam periode transisi sebelum dan sesudah bencana tsunami. Data ditahun sebelum terjadi bencana tsunami yaitu di tahun 2015 2018 dianalisis berdasarkan data perencanaan dan realisasi tahun 2015 - 2018, demikian juga dengan data di tahun 2019 dianalisis berdasarkan data perencanaan dan realisasi di tahun 2019. Analisis yang dilakukan dengan melakukan perhitungan nilai kontribusi pajak parkir dan pajak hotel terhadap pajak daerah Kabupaten Pandeglang sebelum dan sesudah Tsunami selat Sunda.

\section{HASIL DAN PEMBAHASAN}

Hasil dari penelitian ini adalah untuk menjelaskan kontribusi Pajak Hotel dan Pajak Parkir sebagai sumber pendapatan pajak daerah serta mengukur kontribusi realisasi terhadap perencanaan periode tahun 2015 s.d. 2019, dalam kondisi sebelum dan sesudah peristiwa bencana tsunami selat sunda di Kabupaten Pandeglang.

Berdasarkan hasil pengumpulan data dan studi literatur didapatkan informasi sebagaimana tabel 1. Dari tabel 1 dapat terlihat Pajak Daerah Kabupaten Pandeglang dalam 5 (lima) tahun anggaran yaitu di tahun 2015 - 2019 keseluruhan mencapai target, hanya pada tahun 2016 yang berada di bawah target yaitu $99 \%$. Target atas penerimaan Pajak Daerah tertinggi berada di tahun 2017 yaitu sebesar Rp 49.012.933.171 sedangkan penerimaan Pajak Daerah terendah berada di tahun 2015 yaitu sebesar Rp 28.735.834.910. Dari sisi pencapaian atas target, pencapaian tertinggi berada di tahun 2017 yaitu sebesar $221 \%$, sedangkan pencapaian atas target terendah berada di tahun 2016. Dari tabel 1 juga, terlihat bahwa Pemerintahan Daerah (Kabupaten Pandeglang) menargetkan adanya peningkatan pendapatan pajak daerah dari tahun ke tahun termasuk setelah bencana tsunami yaitu dari tahun 2018 ke tahun 2019. Realisasi dari adanya penerimaan pendapatan daerah juga menunjukan hasil yang baik itu sebelum dan sesudah tsunami selat sunda, dengan pencapaian selalu melebihi dari target/ rencana pendapatan yang telah dibuat oleh pemerintah daerah. Keseluruhan sumber pendapatan pajak daerah tersebut sebagaimana Undang - Undang dan Peraturan Daerah nomor 1 tahun 2011 terdiri tidak hanya Pajak Hotel dan Parkir tetapi juga jenis pajak - pajak lainnya seperti Pajak Restoran, Pajak Hiburan, Pajak Reklame, Pajak Penerangan Jalan, Pajak Mineral Bukan Logam dan Batuan, Pajak Air Tanah, Pajak Sarang Burung Walet, Pajak Bumi dan Bangunan Perdesaan dan Perkotaan, dan Bea Perolehan Hak atas Tanah dan Bangunan.

Tabel 1. Target dan Realisasi Pajak Daerah Kabupaten Pandeglang

\begin{tabular}{cccc}
\hline Tahun & Target (Rp) & Realisasi (Rp) & $(\%)$ \\
\hline 2015 & 28.735 .834 .910 & 30.005 .466 .185 & $104 \%$ \\
2016 & 34.044 .668 .910 & 33.732 .241 .562 & $99 \%$ \\
2017 & 35.305 .195 .302 & 77.878 .002 .064 & $221 \%$ \\
2018 & 44.148 .149 .159 & 47.072 .784 .604 & $107 \%$ \\
2019 & 49.012 .933 .171 & 54.704 .078 .841 & $112 \%$ \\
\hline
\end{tabular}

Sumber: Data diolah (2021)

Hasil pengumpulan data dan studi literatur lainnya didapatkan informasi sebagaimana tabel 2. Berdasarkan tabel 2, terlihat nilai realisasi dari tahun 2015 sampai 
dengan 2018 (sebelum tsunami selat sunda) memiliki nilai yang cenderung tetap (tidak terdapat peningkatan), hanya saja apabila dibandingkan dengan nilai realisasi atas penerimaan Pajak Daerah, maka nilai kontribusi Pajak Hotel mengalami penurunan. Kontribusi Pajak Hotel terhadap Pajak Daerah tahun 2019 (setelah terjadi tsunami selat sunda) turun sampai dengan 2 $\%$. Penurunan nilai tersebut akibat sepinya jumlah wisatawan yang menginap di sekitaran wisata Kabupaten Pandeglang. Pajak Hotel menurun seiring dengan menurunnya keadaaan atau kondisi fasilitas serta sarana dan prasarana yang ada di hotel pasca terjadinya tsunami selat sunda. Penurunan nilai kontribusi Pajak Hotel terhadap Pendapatan Pajak Daerah ini, sejalan dengan penelitian Fitriyani (2021) dan Yafitzam (2021) tetapi berbeda dengan penelitian Yohanis (2018).

Tabel 2. Kontribusi Pajak Hotel Terhadap Pajak Daerah Kabupaten Pandeglang

\begin{tabular}{cccc}
\hline Tahun & $\begin{array}{c}\text { Pajak Hotel } \\
(\mathrm{Rp})\end{array}$ & $\begin{array}{c}\text { Pajak Daerah } \\
(\mathrm{Rp})\end{array}$ & $\begin{array}{c}\text { Kontribusi } \\
(\%)\end{array}$ \\
\hline 2015 & 3.052 .585 .977 & 30.005 .466 .185 & $10 \%$ \\
2016 & 3.245 .162 .780 & 33.732 .241 .562 & $10 \%$ \\
2017 & 3.575 .068 .943 & 77.878 .002 .064 & $5 \%$ \\
2018 & 3.495 .778 .095 & 47.072 .784 .604 & $7 \%$ \\
2019 & 1.167 .855 .149 & 4.704 .078 .841 & $2 \%$ \\
\hline
\end{tabular}

Sumber: Data diolah (2021)

Hasil pengumpulan data dan studi literatur juga didapatkan informasi sebagaimana tabel 3. Berdasarkan tabel 3, terlihat kontribusi nilai realisasi Pajak Parkir sebelum dan sesudah terjadi bencana tsunami yaitu dari tahun 2015 sampai dengan tahun 2019 cenderung sama terhadap Pajak Daerah meskipun realisasi tertinggi di setiap tahunnya berada di tahun setelah terjadinya bencana tsunami, artinya antusias wisatawan masih baik walaupun wisatawan cenderung menikmati wisata pantai Kabupaten
Pandeglang dengan tidak menggunakan fasilitas penginapan yang ada.

Pengenaan Pajak Parkir berdasarkan luasan tanah Parkir serta banyaknya jenis/ golongan yang termasuk dalam kategori pajak parkir yang dikenakan kepada orang pribadi maupun badan/ lembaga yang memanfaatkan lahan untuk parkir kendaraan menjadikan adanya peningkatan pajak parkir baik itu sebelum dan sesudah tsunami. Peningkatan nilai kontribusi Pajak Parkir terhadap Pendapatan Pajak Daerah ini, sejalan dengan penelitian Mufidoh (2017) dan Robiyah (2019).

Tabel 3. Kontribusi Pajak Parkir terhadap Pajak Daerah Kab.Pandeglang

\begin{tabular}{cccc}
\hline Tahun & $\begin{array}{c}\text { Pajak } \\
\text { Parkir (Rp) }\end{array}$ & $\begin{array}{c}\text { Pajak } \\
\text { Daerah }(\mathrm{Rp})\end{array}$ & $\begin{array}{c}\text { Kontribusi } \\
(\%)\end{array}$ \\
\hline 2015 & 56.295 .437 & 30.005 .466 .185 & $0,19 \%$ \\
2016 & 41.491 .434 & 33.732 .241 .562 & $0,12 \%$ \\
2017 & 52.788 .455 & 77.878 .002 .064 & $0,07 \%$ \\
2018 & 77.553 .697 & 47.072 .784 .604 & $0,16 \%$ \\
2019 & 83.799 .121 & 54.704 .078 .841 & $0,15 \%$ \\
\hline
\end{tabular}

Sumber: Data diolah (2021)

Hasil pengumpulan data dan studi literatur lainnya didapatkan informasi sebagaimana tabel 4. Tabel 4 menunjukan bahwa Pajak Hotel Kabupaten Pandeglang dalam 4 (empat) tahun target anggaran yaitu di tahun 2015 - 2018 (sebelum tsunami selat sunda) mengalami peningkatan, sedangkan di tahun 2019 (setelah terjadi bencana tsunami) mengalami penurunan. Realisasi penerimaan apabila dibandingkan dengan target atau rencana anggaran untuk tahun 2015 sampai dengan 2018 (sebelum tsunami selat sunda) menunjukan hasil yang baik yaitu di atas 80 $\%$, bahkan ada yang melebihi dari $100 \%$ yaitu di tahun 2015 dan 2017. Penurunan target penerimaan Pajak Hotel, tidak mengurangi usaha dari pemerintah dan para pelaku usaha di bidang perhotelan. Hal ini dapat terlihat dari tercapainya target 
penerimaan atas Pajak Hotel di tahun 2019 (setelah tsunami selat sunda) yaitu sebesar Rp 1.167.855.149 atau sebesaar $104 \%$ dari target yang di tetapkan oleh Pemerintah Daerah.

Tabel 4. Target dan Realisasi Pajak Hotel Kabupaten Pandeglang

\begin{tabular}{cccc}
\hline Tahun & Target $(\mathrm{Rp})$ & Realisasi $(\mathrm{Rp})$ & $(\%)$ \\
\hline 2015 & 2.297 .500 .000 & 3.052 .585 .977 & $133 \%$ \\
2016 & 3.332 .500 .000 & 3.245 .162 .780 & $97 \%$ \\
2017 & 3.350 .213 .902 & 3.575 .068 .943 & $107 \%$ \\
2018 & 3.915 .367 .440 & 3.495 .778 .095 & $89 \%$ \\
2019 & 1.120 .200 .000 & 1.167 .855 .149 & $104 \%$ \\
\hline
\end{tabular}

Sumber: Data diolah (2021)

Hasil pengumpulan data dan studi literatur juga didapatkan informasi sebagaimana tabel 5. Berdasarkan tabel 5, didapatkan informasi bahwa Pemerintah Daerah menargetkan atas Pajak Parkir peningkatan penerimaan dari tahun 2015 sampai dengan tahun 2019 (sebelum dan sesudah bencana tsunami). Dari sisi realisasi juga terjadi peningkatan dari tahun 2015 sampai dengan 2018 (sebelum bencana tsunami), bahkan mengalami peningkatan di tahun 2019 (sesudah bencana tsunami), dan merupakan nilai realisasi yang tertinggi apabila dibandingkan dengan realisasi di tahun 2015 sampai dengan tahun 2018 (sebelum bencana tsunami selat sunda). Walaupun terjadi peningkatan realisasi dari tahun 2015 sampai dengan tahun 2019 atas penerimaan Pajak Parkir tetapi cenderung tidak memenuhi target penerimaan atas Pajak Parkir yang dibuat oleh Pemerintah Kabupaten Pandeglang di setiap tahunnya kecuali hanya ditahun 2015. Ketidaktercapaian terhadap hasil tidak menutup kemungkinan dikarenakan terlalu tingginya target yang di buat oleh Pemerintah Daerah (dalam kondisi setelah bencana tsunami khususnya) serta belum optimalnya pengelolaan penerimaan yang bersumber dari Copyright (C) 2021, FINANCIAL: Jurnal Akuntansi
Pajak Parkir dan kurangnya kesadaran masyarakat untuk membayar iuran atas Pajak Parkir ke Pemerintah Daerah. Tercapainya target penerimaan Pajak Hotel tidak terlepas dari arti pajak yaitu iuran dari masyarakat dimana dengan kondisi pasca bencana perlu ada penyesuaian atas target penerimaan yang dilakukan oleh pemerintah daerah selaku pengelola pajak daerah.

Tabel 5. Target dan Realisasi Pajak Parkir Kabupaten Pandeglang

\begin{tabular}{cccc}
\hline Tahun & Target $(\mathrm{Rp})$ & $\begin{array}{c}\text { Realisasi } \\
(\mathrm{Rp})\end{array}$ & $\begin{array}{c}\text { Persentase } \\
(\%)\end{array}$ \\
\hline 2015 & 50.750 .000 & 56.295 .437 & $111 \%$ \\
2016 & 55.000 .000 & 41.491 .434 & $75 \%$ \\
2017 & 55.556 .700 & 52.788 .455 & $95 \%$ \\
2018 & 100.500 .000 & 77.553 .697 & $77 \%$ \\
2019 & 146.886 .338 & 83.799 .121 & $57 \%$ \\
\hline
\end{tabular}

Sumber: Data diolah (2021)

Data hasil pengumpulan dan studi literatur didapatkan informasi sebagaimana tabel 6. Berdasarkan tabel 6, didapatkan informasi sebelum dan sesudah bencana tsunami bahwa terjadi kenaikan realisasi Pajak Hotel setiap tahunnya dari tahun 2015 sampai dengan tahun 2017, dan penurunan realisasi Pajak Hotel di tahun 2018 dan 2019. Penurunan realisasi penerimaan Pajak Hotel di tahun 2018 (sebelum bencana tsunami selat sunda) tidak terlalu signifikan yaitu sebesar 2,22 \% atau sebesar Rp 79.290.848, sedangkan untuk penurunan realisasi penerimaan Pajak Hotel di tahun 2019 (setelah bencana tsunami selat sunda) cukup tinggi sebesar $66,59 \%$ atau sebesar $\mathrm{Rp}$ 2.327.922.946. Penurunan realisasi penerimaan Pajak Hotel di tahun 2019 diantaranya karena beberapa sarana dan prasanana serta bangunan hotel banyak yang mengalami kerusakan sehingga perlu mengalami perbaikan, disamping menurunkan wisatawan datang setelah terjadinya bencana tsunami. Rasa takut pasca 
tsunami, masih dirasakan sebagian para wisawatan untuk menginap di hotel - hotel di Kabupaten Pandeglang, khususnya di daerah sekitar pantai.

Tabel 6. Kenaikan/ Penurunan Realisasi Pajak Hotel Kabupaten Pandeglang

\begin{tabular}{cccc}
\hline Tahun & $\begin{array}{c}\text { Pajak Hotel } \\
(\mathrm{Rp})\end{array}$ & $\begin{array}{c}\text { Kenaikan/ } \\
\text { Penurunan }\end{array}$ & $\begin{array}{c}\text { Persentass } \\
(\%)\end{array}$ \\
\hline 2015 & 3.052 .585 .977 & & \\
2016 & 3.245 .162 .780 & 192.576 .803 & $6,31 \%$ \\
2017 & 3.575 .068 .943 & 329.906 .163 & $10,17 \%$ \\
2018 & 3.495 .778 .095 & $(79.290 .848)$ & $-2,22 \%$ \\
2019 & 1.167 .855 .149 & $(2.327 .922 .946)$ & $-66,59 \%$ \\
\hline
\end{tabular}

Sumber: Data diolah (2021)

Hasil pengumpulan data dan studi literatur didapatkan informasi sebagaimana tabel 7. Berdasarkan tabel 7, didapatkan informasi bahwa terjadi kenaikan realisasi Pajak Parkir setiap tahunnya dari tahun 2015 sampai dengan tahun 2019, kecuali di tahun 2016 terjadi penurunan sebesar Rp 14.804.003 atau sebesar $26 \%$. Kenaikan realisasi penerimaan Pajak Hotel (sebelum bencana tsunami selat sunda) terjadi di tahun 2017 yaitu sebesar $27 \%$ dan sebesar 47\% di tahun 2018. Kenaikan realisasi penerimaan Pajak Parkir di tahun 2019 tidak menunjukan hasil yang lebih baik bila dibandingkan dengan kenaikan tahun - tahun sebelum terjadinya bencana tsunami , walaupun demikian cukup menandakan kalau masih banyak kendaraan yang singgah/ menempat sementara untuk bisa berkunjung di daerah Kabupaten Pandeglang.

Tabel 7.Kenaikan/ Penurunan Pajak Parkir Kabupaten Pandeglang

\begin{tabular}{cccc}
\hline Tahun & $\begin{array}{c}\text { Pajak Hotel } \\
(\mathrm{Rp})\end{array}$ & $\begin{array}{c}\text { Kenaikan/ } \\
\text { Penurunan }\end{array}$ & $\begin{array}{c}\text { Persentase } \\
(\%)\end{array}$ \\
\hline 2015 & 56.295 .437 & - & - \\
2016 & 41.491 .434 & $(14.804 .003)$ & $-26 \%$ \\
2017 & 52.788 .455 & 11.297 .021 & $27 \%$ \\
2018 & 77.553 .697 & 24.765 .242 & $47 \%$ \\
2019 & 83.799 .121 & 6.245 .424 & $8 \%$ \\
\hline
\end{tabular}

Sumber: Data diolah (2021)

Copyright (C) 2021, FINANCIAL: Jurnal Akuntansi

\section{SIMPULAN DAN SARAN}

Pemerintahan Daerah Kabupaten Pandeglang menargetkan adanya peningkatan pendapatan pajak daerah dari tahun 2015 s.d. 2018 (tahun sebelumnya terjadinya bencana tsunami selat sunda) dan juga di tahun 2019 (tahun setelah terjadinya bencana tsunami selat sunda). Kontribusi Pajak Hotel terhadap Pajak Daerah sebelum dan sesudah terjadi bencana tsunami selat sunda mengalami penurunan. Persentase kontribusi penerimaan yang cenderung menurun di tahun 2019 dikarenakan adanya peningkatan target penerimaan atas Pajak Daerah. Persentase kontribusi Pajak Parkir terhadap Pajak Daerah sebelum terjadi bencana tsunami selat sunda cenderung tetap (tidak terdapat peningkatan), kecuali di tahun 2019 (setelah bencana tsunami) yang cenderung meningkat serta berbanding lurus dengan target penerimaan atas Pajak Parkir Kabupaten Pandeglang yang meningkat.

Saran bagi Pemerintah Daerah Kabupaten Pandeglang yaitu melakukan kajian terkait dengan penentuan target pajak dengan memperhitungkan tidak hanya kondisi keuangan dan ekonomi tetapi juga psikologi sosial. Pemerintah diharapkan juga lebih proaktif melakukan sosialisasi memberikan informasi dan bimbingan kepada wajib pajak dalam melakukan pembayaran pajak terutang dan juga memberikan motivasi untuk bangkit demi pembangunan kembali Kabupaten Pandeglang.

\section{DAFTAR PUSTAKA}

Aji, F. B. (2021). Faktor-Faktor yang Mempengaruhi Pajak Daerah Kota Semarang. Diponegoro Journal of Economics, 10(2013), 1-12. https://ejournal3.undip.ac.id/index.php/j me/article/view/29995

Aznedra, A. (2017). Pengaruh Kontribusi 
Penerimaan Pajak Hotel Dan Pajak Restoran Terhadap Pendapatan Asli Daerah Di Wilayah Kota Batam Tahun 2012-2014 (Studi Kasus Dinas Pendapatan Asli Daerah di Kota Batam). Jurnal Dimensi, 6(2), 235-255. https://doi.org/10.33373/dms.v6i2.1049

Fitriyani, E., Hendri, N., \& Ali, K. (2021). Analisis Laju Pertumbuhan, Efektivitas Kontribusi Pajak Hotel dan Pajak Restoran dalam Peningkatan Pendapatan Asli Daerah (PAD) di Kota Metro. Jurnal Ilmiah Keuangan, 4(1), 70-85.

Mardiasmo. (2018). Perpajakan Edisi Terbaru 2018. Andi.

Mufidah, A., Susyanti, J., \& Slamet, A. rachmat. (2017). Analisis Pengaruh Pajak Parkir, Pajak Restoran dan Retribusi Parkir Terhadap Pendapatan Asli Daerah Kota Malang (Studi Kasus Badan Pengelola Keuangan dan Aset Daerah Kota Malang). Jurnal Ilmiah Riset Manajemen, 6(02), 29-44. http://www.riset.unisma.ac.id/index.php /jrm/article/view/133/127

Peraturan Daerah Kabupaten Pandeglang No. 1 tentang Pajak Daerah, (2011).

Pratama, R., Sudarmanto, E., \& Timuriana, T. (2017). Pendapatan Asli Daerah Kota Bogor. Jurnal Online Mahasiswa (JOM) Bidang Akuntansi, 5.

Puspita, R. A., Wilopo, \& Prasetya, A. (2016). Peran Pemungutan Pajak Parkir Dalam Peningkatan Pendapatan Asli Daerah Di Kota Malang. Jurnal Perpajakan (JEJAK)|, 8(1), 1-6.

Rabiyah, U. (2019). Analisis Penerapan Potensi dan Efektifitas Pajak Parkir dan Retribusi Parkir Untuk Meningkatkan Pendapatan Asli Daerah Kota Makassar. Movere Journal, 3(1), 59-69. http://ojs.stietdn.ac.id/index.php/MV/article/view/33

Siregar, B. (2017). Akuntansi Sektor Publik: Akuntansi Keuangan Pemerintahan Daerah Berbasis Akrual. In .: Vol. Edisi II (Issue Yogyakarta: UPP STIM YKPN). UPP STIM YKPN.

Sugiyono. (2019). Metode Penelitian

Copyright (C) 2021, FINANCIAL: Jurnal Akuntansi
Kuantitatif, Kualitatif dan $R \& D . C V$. Alfabeta.

Undang - Undang Republik Indonesia Nomor 28 tentang Pajak Daerah dan Restribusi Daerah, (2009).

Widodo, W. I., \& Guritno, B. (2017). Pengaruh Pajak Hotel, Pajak Restauran Dan Pajak Hiburan Terhadap Pendapatan Asli Daerah (PAD) Di Kota Yogyakarta. Junal Visi Manajemen, 2(2), 128-138. http://stiepari.greenfrogts.co.id/jurnal/index.php/JVM/article/vie $\mathrm{w} / 79 / 82$

Yafitzam, Y. (2021). Analisis Kontribusi Pajak Hotel Terhadap Pendapatan Asli Daerah. Jurnal Kebangsaan, 10(19).

Yohanis, B. (2018). Analisis Efektivitas, Kontribusi Pajak Hotel Dan Pajak Restoran Pada Pendapatan Asli Daerah (Pad) Kabupten Sleman. Jurnal Ekobis Dewantara, 1(9).

Yusmalina, Lasita, \& Fauzan, H. (2020). Analisis Pengaruh Pajak Daerah Dan Retribusi Daerah. Jurnal Cafetaria, 1(1), 13-21. 